\title{
EFEKTIVITAS PEMBERIAN DAUN BINAHONG (ANREDERA CORDIFOLIA (TENORE) STEEN) DAN POVIDONE IODINE 10\% TERHADAP PENYEMBUHAN LUKA PERINEUM
}

\author{
Dewi Yuliana* $\diamond$, Aulia Rahman*, Gustop Amatiria** \\ *Prodi Keperawatan Universitas Mitra Indonesia \\ **Jurusan Keperawatan Poltekkes Kemenkes Tanjungkarang \\ $\checkmark$ Corresponding Outhor: Dewiyuliana429@yahoo.co.id
}

\begin{abstract}
Infeksi perlukaan jalan lahir merupakan morbiditas dan mortalitas bagi ibu pasca bersalin. Kasus luka perineum pada ibu melahirkan masih tinggi. Penelitian ini bertujuan untuk mengetahui efektivitas pemberian daun binahong (Anredera Cordifolia (Tenore) Steen) dan Povidone Iodine 10\% terhadap penyembuhan luka perineum. Penelitian ini merupakan jenis penelitian kuantitatif Quasi Eksperimental dengan rancangan non randomized control group pre test - post test design. Populasi dalam penelitian ini adalah ibu Post Partum yang mengalami luka perineum dengan sampel sebanyak 76 responden, yang dibagi menjadi 2 kelompok intervensi yaitu kelompok yang diberikan daun binahong dan kelompok yang diberikan povidone iodine. Pengumpulan data dilakukan dengan menggunakan lembar observasi pengkajian perkembangan luka perineum. Analisis data menggunakan uji McNemar dan uji regresi logistic. Hasil penelitian menunjukkan ada perbedaan penyembuhan luka perineum pada intervensi daun binahong dan povidone idodine dengan $p$ value sebesar 0,000. Artinya, bahwa daun binahong lebih efektif untuk penyembuhan luka perineum dibandingkan Povidone Iodine 10\%. Rekomendasi yaitu bekerja sama dengan bagian Farmasi untuk memproduksi obat herbal dalam bentuk cream atau salep yang terbuat dari bahan baku daun binahong.
\end{abstract}

Kata Kunci: Binahong, povidone Iodine, luka perineum

\section{LATAR BELAKANG}

Salah satu program pemerintah di bidang kesehatan adalah Sustainable Development Goals (SDGs), yaitu sebuah dokumen yang akan menjadi sebuah acuan dalam kerangka pembangunan dan perundingan negara-negara di dunia. Cakupan tujuan dari SDGs yang terdiri dari tujuh belas (17) tujuan dan target SDGs naik menjadi 17 goals, 169 target dan 252 indikator, Salah satu tujuannya adalah menurunan AKI sampai dengan angka 70 per 100 ribu kelahiran hidup pada tahun 2015.

Beberapa hal dapat terjadi pada saat masa nifas, salah satunya ialah infeksi masa nifas. Infeksi nifas merupakan morbiditas dan mortalitas bagi ibu pasca bersalin. Asuhan masa nifas diperlukan dalam periode ini karena merupakan masa kritis baik ibu maupun bayinya. Infeksi yang terjadi salah satunya ialah infeksi perlukaan jalan lahir. Perawatan luka perineum pada ibu setelah melahirkan berguna untuk mengurangi rasa ketidaknyamanan, menjaga kebersihan, mencegah infeksi dan mempercepat penyembuhan luka. Infeksi masa nifas adalah penyebab kematian maternal yang merupakan urutan kedua setelah perdarahan jika tidak segera ditangani. Kejadian infeksi masa nifas dapat terjadi di traktus genitalia apabila setelah kelahiran ibu nifas tidak melakukan perawatan perineum dengan baik, infeksi dapat terjadi diakibatkan oleh bakteri. Ruptur perineum dapat terjadi karena ruptur spontan maupun episiotomi. Robekan jalan lahir dapat menyebabkan perdarahan, oleh karena itu dilakukan penjahitan perineum. Kualitas luka jahitan perineum dikatakan baik apabila tidak terdapat tanda - tanda infeksi yaitu, merah, bengkak, panas, nyeri, fungsioleosa (Mochtar, 2011).

Seiring perkembangan zaman, pemakaian dan pendayagunaan obat herbal di Indonesia mengalami kemajuan yang sangat pesat. Obat-obatan herbal digunakan kembali oleh masyarakat sebagai salah satu alternatif pengobatan, di samping obat - obatan modern yang berkembang pesat di pasar obat herbal yang berasal dari tumbuhan dan bahan - bahan alami murni memiliki efek samping, tingkat bahaya dan resiko yang jauh lebih rendah dibandingkan dengan obat kimia (Rochani, 2009). 
Salah satu tumbuhan yang biasa digunakan untuk obat herbal adalah tumbuhan binahong (Anredera Cordifolia). Masyarakat menggunakan binahong untuk menyembuhkan luka. Sebagai obat luka, binahong mengandung beberapa kandungan kimia yaitu flavonoid, asam oleanolik, protein, saponin dan asam askorbat. Kandungan asam askorbat pada tanaman ini penting untuk mengaktifkan enzim prolil hidroksilase yang menunjang tahap hidroksilasi dalam pembentukan kolagen, sehingga dapat mempercepat proses penyembuhan luka. Sebagai respon dari kerusakan jaringan tersebut, maka tubuh akan berusaha untuk memperbaiki jaringan yang rusak melalui mekanisme penyembuhan luka. Untuk membantu penyembuhan luka dapat menggunakan daun binahong (Katno, 2006).

Saponin juga mempunyai aktivitas antiseptik dan pembersih serta meningkatkan kekebalan tubuh. Polifenol merupakan senyawa turunan fenol yang mempunyai aktivitas sebagai antioksidan yang berpengaruh dalam mengurangi oksidan berlebih yang dikeluarkan oleh sel PMN (Polimorphonuclear) pada fase I penyembuhan luka. Flavonoid selain memiliki efek antioksidan juga memiliki sifat antibakterial (Hernani, 2005).

Larissa,Wulan dan Prabowo (2017) dalam artikelnya juga mengatakan bahwa daun binahong memiliki berbagai kandungan yaitu saponin, flavonoid, alkaloid, polifenol, asam askorbat, asam oleanolik yang mempunyai sifat anti bakteri dimana infeksi merupakan salah satu penghambat penyembuhan luka bakar. Beberapa bakteri seperti Pseudomonas aeruginosa, Staphylococcus aureus, Escherichia coli, Klebsiella spp. Enterococcus spp merupakan kontaminan utama pada luka bakar, selain sebagai anti bakteri kandungan tersebut juga mempunyai sifat seperti antiinflamasi, analgetik, dan antoksidan. Berbagai kandungan tersebut dapat mempercepat penyembuhan luka bakar derajat II.

Studi pendahuluan yang dilakukan di Dinas Kesehatan kota Bandar Lampung tahun 2016 terdapat ibu nifas sebanyak 941 orang, namun data tentang luka perineum ibu nifas belum ada pelaporan atau catatan yang lengkap dari setiap Puskesmas. Salah satu penyebabnya adalah karena lemahnya sistem pemantauan, pencatatan dan pelaporan petugas kesehatan dalam pelaksanaan pelayanan ibu masa bersalin dan nifas. Berdasarkan wawancara pada petugas kesehatan di Puskesmas Rawat Inap Kedaton Bandar Lampung, kasus luka perineum, baik karena ruptur perineum spontan dan episiotomi yang dialami ibu melahirkan di Kecamatan Kedaton tahun 2016 masih sangat tinggi yaitu sekitar $60 \%$ dari 941 persalinan normal (DinKes Provinsi Lampung, 2016). Sedangkan data persalinan normal dari bulan Januari-Februari 2017 diketahui bahwa jumlah ibu bersalin sebanyak 145 orang, dan terdapat luka pada perineum karena episiotomi dan robekan spontan sebanyak 16 orang.Menurut petugas kesehatan untuk angka kejadian infeksi masa nifas tidak ada catatan tertulis, tetapi dari jumlah ibu nifas tersebut terdapat 9 orang mengalami penyembuhan luka diatas 10 hari yaitu luka belum kering, dan kejadian tersebut Puskesmas segera merujuk ke RS. Berdasarkan hasil wawancara kepada 8 orang ibu nifas di wilayah Kecamatan Kedaton, bahwa fenomena menggunakan bahan tradisional seperti daun sirih dan daun binahong untuk mengobati luka jahit setelah melahirkan sudah dipakai sejak turuntemurun.

\section{METODE}

Rancangan penelitian ini menggunakan rancangan Quasi Eksperimental (Eksperimen Semu) dengan rancangan non randomized control group pre test - post test design. Penelitian dirancang untuk membandingkan efektifitas penyembuhan luka perineum pada kelompok yang diberikan daun binahong (kelompok A) dan kelompok yang diberikan povidone iodine 10\% (kelompok $\mathrm{B}$ ).

Populasi dalam penelitian ini adalah ibu post partum spontan yang mengalami luka perineum di Kecamatan Kedaton Bandar Lampung dibulan April dan Mei yaitu sebanyak 150 orang. Dengan menggunakan teknik Purposive Sampling diperoleh jumlah 
sampel sebanyak 76 responden. Adapun kriteria responden meliputi: ibu post partum spontan hari ke-4, dengan luka heacthing (jahitan perineum), sudah mendapat terapi antibiotik, bersedia mengisi informed consent, tidak ada komplikasi persalinan dan tidak mempunyai penyakit yang dapat mengganggu penyembuhan luka seperti penyakit Diabetes Melitus.

Pengumpulan data dilakukan dengan menggunakan lembar observasi pengkajian perkembangan luka perineum. Analisis data yang digunakan yaitu analisis univariat, bivariat uji McNemar dan multivariat uji regresi logistic.

\section{HASIL}

\section{Analisis Univariat}

Tabel 1: Distribusi Responden Berdasarkan Usia, Agama, Suku, Pendidikan, Pekerjaan, Paritas, Personal Hygiene, Gizi dan Penyembuhan Luka Perineum

\begin{tabular}{|c|c|c|c|c|}
\hline \multirow{2}{*}{ Variabel } & \multicolumn{4}{|c|}{ Klpk A Klpk B Total } \\
\hline & f $\%$ & f $\%$ & & $\%$ \\
\hline \multicolumn{5}{|l|}{ Usia } \\
\hline Dewasa lanjut & 1744,7 & 1128,9 & 28 & 36,8 \\
\hline Dewasa awal & 1950,0 & 2360,5 & 42 & 55,3 \\
\hline Remaja & 25,3 & $4 \quad 10,5$ & 6 & 7,9 \\
\hline \multicolumn{5}{|l|}{ Agama } \\
\hline Non Islam & $0 \quad 0$ & 25,3 & & 2,7 \\
\hline Islam & 38100 & 3694,7 & 74 & 97,3 \\
\hline \multicolumn{5}{|l|}{ Suku } \\
\hline Jawa & 923,7 & 1642,1 & 25 & 32,9 \\
\hline Sumatera & 2976,3 & 2257,9 & 51 & 67,1 \\
\hline \multicolumn{5}{|l|}{ Pendidikan } \\
\hline Rendah (SD, SMP) & 410,5 & 615,8 & 10 & 13,2 \\
\hline Tinggi (SMU, PT) & 3489,5 & 3284,2 & 66 & 86,8 \\
\hline \multicolumn{5}{|l|}{ Pekerjaan } \\
\hline Tidak bekerja & 2873,7 & 3078,9 & 58 & 76,3 \\
\hline Bekerja & 1026,3 & $8 \quad 21,1$ & & 23,7 \\
\hline \multicolumn{5}{|l|}{ Paritas } \\
\hline Primiparitas & 1128,9 & 1436,8 & 25 & 32,8 \\
\hline Multiparitas & 2771,1 & 2463,2 & 51 & 67,2 \\
\hline \multicolumn{5}{|l|}{ Personal Hygiene } \\
\hline Kurang & 2360,5 & 2155,3 & 44 & 57,9 \\
\hline Baik & 1539,5 & 1744,7 & & 42,1 \\
\hline \multicolumn{5}{|l|}{$\overline{\text { Gizi }}$} \\
\hline Kurang & 2257,9 & 1744,7 & 39 & 51,3 \\
\hline Baik & 1642,1 & 2155,3 & 37 & 48,7 \\
\hline \multicolumn{5}{|l|}{ Penyembuhan luka } \\
\hline Normal & 923,7 & 2155,3 & 30 & 39,5 \\
\hline Cepat & 2976,3 & 1744,7 & 46 & 60,5 \\
\hline
\end{tabular}

Hasil penelitian menunjukkan sebagian besar responden merupakan kelompok ibu usia dewasa awal (20 - 30 tahun) sebanyak 42 orang $(55,3 \%)$, agama Islamsebanyak 74 orang $(97,3 \%)$,suku Sumatera sebanyak 51 orang $(67,1 \%)$,pendidikan tinggi (SMU, PT) sebanyak 66 orang $(86,8 \%)$, ibu tidak bekerja sebanyak 58 orang $(76,3 \%)$, multiparitas sebanyak 51 orang $(67,2 \%)$, personal hygiene kurang sebanyak 44 orang $(57,9 \%)$, gizi kurang sebanyak 39 orang $(51,3 \%)$, dan penyembuhan luka perineum cepat sebanyak 46 orang $(60,5 \%)$.

\section{Analisis Bivariat}

Tabel 2: Distribusi Perbedaan Penyembuhan Luka Perineum Sebelum dan Sesudah Intervensi pada Kelompok A dan Kelompok B

\begin{tabular}{|c|c|c|c|c|}
\hline \multirow{2}{*}{ Penyembuhan Luka } & \multicolumn{2}{|c|}{$\begin{array}{c}\text { Penyembuhan } \\
\text { Luka Perineum } \\
\text { Post Test }\end{array}$} & \multirow{2}{*}{ Total } & \multirow{2}{*}{$\begin{array}{c}p \\
\text { value }\end{array}$} \\
\hline & $\begin{array}{c}\text { Normal } \\
(7-14 \\
\text { hari }) \\
\end{array}$ & $\begin{array}{c}\text { Cepat } \\
(1-6 \\
\text { hari }) \\
\end{array}$ & & \\
\hline \multicolumn{5}{|l|}{ Kelompok A } \\
\hline \multicolumn{5}{|l|}{ Penyembuhan Luka } \\
\hline Normal : (7 - 14 hari) & 8 & 24 & 32 & 0,000 \\
\hline Cepat $:(1-6$ hari $)$ & 1 & 5 & 6 & \\
\hline \multicolumn{5}{|l|}{ Kelompok B } \\
\hline \multicolumn{5}{|l|}{ Penyembuhan Luka } \\
\hline Normal : (7 - 14 hari) & 19 & 10 & 29 & 0,039 \\
\hline Cepat : ( $1-6$ hari $)$ & 2 & 7 & 9 & \\
\hline
\end{tabular}

Hasil uji statistik diperoleh nilai $p=$ $0,000<0,05$. Ini dapat disimpulkan bahwa ada perbedaan penyembuhan luka perineum sebelum dan sesudah pemberian daun binahong.

Tabel 3: Distribusi Perbedaan Hari Penyembuhan Luka Perineum pada Kelompok A dan Kelompok B

\begin{tabular}{lcccc}
\hline Variabel & Kelompok & $\mathrm{n}$ & Mean & p value \\
\hline Penyembuhan Luka & A & 38 & 6,26 & \multirow{2}{*}{0,000} \\
Perineum & B & 38 & 7,61 & \\
\hline
\end{tabular}


Hasil penelitian menunjukkan bahwa ada perbedaan yang bermakna terhadap penyembuhan luka perineum setelah diberikan intervensi daun binahong dengan $P$ value sebesar 0,000. Artinya, bahwa daun binahong lebih efektiv untuk penyembuhan jahitan luka perineum pada ibu post partum dibandingkan dengan penggunaan Povidone Iodine 10\%di Kecamatan Kedaton Bandar Lampung.

\section{Analisis Mulitvariat}

Tabel 4: Pemodelan Terakhir Analisis Multivariat Regresi Logistik

\begin{tabular}{lccc}
\hline Variabel & $p$ value & OR & $95 \%$ CI \\
\hline Intervensi & 0,004 & 4,467 & $1,608-12,406$ \\
P. Hygiene & 0,810 & 0,862 & $0,258-2,885$ \\
Gizi & 0,263 & 2,008 & $0,592-6,807$ \\
\hline
\end{tabular}

Hasil uji statistik regresi logistik diketahui bahwa semakin besar nilai OR (expB) untuk variabel yang signifikan, maka semakin besar pengaruhnya terhadap variabel dependen yang dianalisis. Dalam data ini berarti gizi yang paling besar pengaruhnya terhadap penyembuhan luka perineum dengan nilai OR $(\operatorname{expB})=2,008$.

\section{PEMBAHASAN}

Penyembuhan luka lebih cepat terjadi pada usia muda dari pada orang tua, karena orang yang sudah lanjut usianya tidak dapat mentolerir stress seperti trauma jaringan atau infeksi. Kulit utuh pada orang dewasa muda yang sehat merupakan suatu barier yang baik terhadap trauma mekanis dan juga infeksi, begitu juga dengan efisiensi sistem imun yang memungkinkan penyembuhan luka perineum lebih cepat.

Leininger terdapat 7 (tujuh) komponen dalam sunrise model yang diantaranya adalah faktor pendidikan, semakin tinggi pendidikan individu, maka keyakinannya harus didukung oleh bukti-bukti ilmiah yang rasional dan dapat beradaptasi terhadap budaya yang sesuai dengan kondisi kesehatannya serta kemampuan belajar secara aktif mandiri tentang pengalaman sakit dan cara penyembuhannya. Demikian juga dengan pendidikan semakin tinggi, maka kepeduliannya terhadap perawatan diri semakin baik.

Hasil penelitian didapat sebagian besar responden dengan Multiparitas. Melalui pengalaman dimasa lalu seseorang dapat belajar cara merawat diri.

Secara empiris tanaman binahong dikenal dapat menyembuhkan luka (Sumartiningsih, 2011). Hasil ini sejalan dengan penelitian Prayudi (2009) yang mengatakan bahwa seluruh bagian tanaman binahong mulai dari akar, umbi, batang, daun dan bunga sangat mujarab untuk terapi herbal. Kemampuan binahong untuk menyembuhkan berbagai jenis penyakit ini berkaitan erat dengan senyawa aktif yang terkandung di dalamnya seperti flavonoid, alkaloid, terpenoid dan saponin. Flavonoid dapat berperan langsung sebagai antibiotik dengan mengganggu fungsi dari mikroorganisme seperti bakteri dan virus. Alkaloid adalah bahan organik yang mengandung nitrogen sebagai bagian dari sistem heterosiklik. Alkaloid memiiliki aktivitas hipoglikemik. Senyawa terpenoid adalah senyawa hidrokarbon isometrik membantu tubuh dalam proses sintesa organik dan pemulihan sel -sel tubuh. Sedangkan saponin dapat menurunkan kolesterol, mempunyai sifat sebagai antioksidan, antivirus dan antikarsinogenik dan manipulator fermentasi rumen.

Povidone Iodine merupakan iodine kompleks yang berfungsi sebagai antiseptik, mampu membunuh mikroorganisme seperti bakteri, jamur, virus, protozoa, dan spora bakteri.

Beberapa penelitian yang telah dilakukan sebelumnya antara lain oleh Miladiyah (2012), yang menyatakan bahwa ekstrak etanol daun binahong mampu menyembuhkan luka lebih baik daripada povidone iodine pada kulit kelinci. Penelitian tersebut juga didukung oleh Kaur (2014), 
yang menyatakan bahwa aplikasi pasta daun binahong secara topikal menunjukkan hasil lebih baik dalam proses penyembuhan luka dibandingkan dengan $\mathrm{NaCl} \quad 0,9 \%$ dan povidone iodine pada kulit tikus, sehingga bisa digunakan sebagai alternatif pengobatan luka dirumah yang bersifat tradisional.

Ektrak Etanol daun binahong juga memiliki kapasitas sebagai antioksidan (Selawa, 2013). Pemberian daun binahong pada luka membantu penyembuhan luka dengan pembentukan jaringan granulasi yang lebih banyak dan repitalisasi terjadi lebih cepat dibandingkan dengan luka yang tidak diberikan daun binahong (Ariani, 2013).

Mutiara, Nurdiana \& Utami (2015) dalam artikelnya juga menyatakan bahwa binahong (Anredera cordifolia (Ten.) Steenis) dapat sebagai antiinflamasi. Hal ini diperkirakan karena adanya senyawa golongan flavonoid dan asam ursolat. Mekanisme flavonoid dalam menghambat proses terjadinya inflamasi melalui efek penghambatan pada jalur metabolisme asam arakhidonat, pembentukan prostaglandin, dan pelepasan histamin pada radang. Jadi pada fase ini makrofag bisa dengan mudah menjalankan fungsinya sebagai fagosit bagi sel-sel debris dan mikroorganisme lain yang ada dalam luka.

Menurut Smeltzer (2010) menyatakan bahwa penyembuhan luka perineum dapat dipengaruhi oleh nutrisi yang adekuat, kebersihan, istirahat, posisi, umur, penanganan jaringan, hemoragi, hipovolemia, edema, defisit oksigen, penumpukan drainase, medikasi, over aktifitas, gangguan sistemik, dan status imunosupresi.

Hal ini sejalan dengan teori yang dikemukakan oleh Kang Kapuk (2012) yang menyatakan bahwa faktor gizi atau nutrisi terutama protein akan sangat mempengaruhi terhadap proses penyembuhan luka pada perineum karena pergantian jaringan sangat membutuhkan protein. Dengan terwujudnya semua makanan yang dianjurkan untuk ibu nifas maka proses penyembuhan luka akan semakin cepat sembuh dan kering.

\section{KESIMPULAN}

Penyembuhan luka perineum sebelum dan sesudah diberikan intervensi daun binahong didapatkan pada kedua kelompok menunjukkan adanya perbedaan yang bermakna, dimana nilai statistik kelompok intervensi lebih kecil dari pada kontrol. Hasil penelitian menunjukkan bahwa daun binahong lebih efektiv untuk penyembuhan jahitan luka perineum pada ibu post partum dibandingkan dengan penggunaan Povidone Iodine $10 \%$.

\section{DAFTAR PUSTAKA}

Ariani, Suci.(2013). Khasiat Daun Binahong (Anredera Cordifolia (Ten.) Steenis) Terhadap Pembentukan Jaringan Granulasi Dan Reepitelisasi Penyembuhan Luka Terbuka Kulit Kelinci

http://ejournal.unsrat.ac.id/index.php/

Dinas Kesehatan Provinsi Lampung. (2016). Profil Kesehatan Provinsi Lampung Tahun 2014. Bandar Lampung: Dinas Kesehatan Provinsi Lampung.

Hernani dan Rahardjo. (2005). Tanaman Berkhasiat Antioksidan. Jakarta: Penebar Swadaya

Kang Kapuk.(2012). Perawatan Luka Perineum Post Partum. (http://perawatanlukaperineum.com/13/ 12/2012)

Katno, Pramono, S. (2006). Tingkat Manfaat dan Keamanan Tanaman Obat Tradisional. Fakultas Farmasi Universitas Gajah Mada. Yogyakarta

Kaur, S, Mondal, P.(2014). Study of Total Phenolic and Flavonoid Content, Antioxidant Activity and Antimicrobial Properties of Medicinal Plants Citation, J Microbiol.

Larissa, U; Wulan, AJ \& Prabowo, AY. (2017). Pengaruh Binahong terhadap Luka Bakar Derajat II. Mojority. 7(1): 130-134.

Miladiyah. (2012). Ethanolic exctract of anredera cordifolia (Ten.) Steenis Leaves Improved Wound Healing In Guinea Pig. Universa Medicina. 31(1). 
Mochtar, R. (2011). Sinopsis Obstertri. Jakarta : EGC

Mutiara, G; Nurdiana \& Utami, YW. (2015). Efektifitas Hidrogel Binahong (Anredera cordifolia (Ten.) Steenis) terhadap Penurunan Jumlah Makrofag pada Penyembuhan Luka Fase Proliferasi Tikus Putih (Rattus norvegicus) Galur Wistar Kondisi Hiperglikemia. Majalah Kesehatan FKUB. 2(1): 29-40.

Prayudi. (2009). Warta Balai Penelitian Tanaman Rempah dan Obat. http://www.digilib.unimus.ac.id
Selawa, W; Revolta, M; Runtuwene, J \& Citraningtyas, G. (2013). Kandungan Flavonoid Dan Kapasitas Antioksidan Total Ekstrak Etanol Daun Binahong. Pharmacon, Jurnal Ilmiah Farmasi UNSRAT. 2(1).

Smeltzer, S.C, \& Bare, B.G. Hinkle, J.L. \& Cheever, K.H. (2010). Texbook Of Medikal Surgical Nursing (11th ed). Philladelphia: Lipincott Williams \& Wilknis

Sumartiningsih, S.(2011). The Effect of Binahong to Hematoma. Word Academy of Science. 78: 743 - 745. 